\title{
Risks and Opportunities of Participation in Global Value Chains
}

\author{
Gary Gereffi \\ Duke University \\ Xubei Luo \\ The World Bank
}

Received: 21 January 2015 / Revised: 10 May 2015 / Accepted: 15 May 2015 / Published online: 17 August 2015

\begin{abstract}
Risk is inherent to the pursuit of opportunity. This paper draws on the recent literature and looks at the risks and opportunities firms and their workers face in the global value chains. First, it examines the sharing mechanisms that firms provide from the national and global perspectives; second, it takes a closer look at the new opportunities and challenges for firms and individuals in the global arena; third, it discusses the role of economic upgrading and social upgrading; and finally it sheds light on how the government can help people manage risks and reap the benefits of participation in global value chains.
\end{abstract}

JEL classification: F63, F68, L22, L23

Key words: Risk; global value chains; economic upgrading; social upgrading; global recession

\section{INTRODUCTION}

For millennia, the ancient agrarian cycle based on crops and livestock controlled the fortunes of the world. Then came the Industrial Revolution in the mid-19 ${ }^{\text {th }}$ century. "For the first time in history, the living standards of the masses of ordinary people have begun to undergo sustained growth," notes Nobel laureate and economist Robert E. Lucas, Jr. "Nothing remotely like this economic behavior has happened before" (Lucas, 2002). More recently, in the context of integration and modernization, waves of technology improvement since the first industrial revolution have been changing the boundary of production, and redefining the spectrum of the role of state. Participation in global value chains (GVCs), which highlight the ways in which new patterns of international trade, production, and employment shape prospects for development and competitiveness, creates opportunities and risks to the enterprises. On the one hand, it creates new opportunities for profits and expands the market horizon; and on the other hand, it exposes the enterprise sector to risks previously shielded from market boundaries and geographic distance, and increases the degree of potential information asymmetry. Various forces interact in different directions, exacerbating or mitigating the dynamics of risks.

Risk implies the possibility of loss. The upside of risk, or the possibility of gain, is opportunity. Risk (or opportunity) can be imposed from outside or taken on voluntarily in the pursuit of opportunities. Enterprises are facing a wide range of risks on a day-to-day basis. Due to continual 
changes in technology, production frontiers are pushing outwards, and higher efficiency becomes the norm for survival (for example, personal computers). Demand changes as new tastes and preferences create niches for new products, and the higher profit mark-up from innovation becomes an engine of growth (for example, the iPad). There are also catastrophic risks from unexpected events such as global economic crises and natural disasters.

The information and communication technology revolution has not only sharply increased productivity, but also reinterpreted the function of time and distance. Billions of activities are linked with "one-click" and new demands become effective with "just-in-time" delivery. The world is increasingly interconnected. The largely unforeseen changes in the global arena - from the collapse of the dot.com boom in the early 2000s, to the burst of housing bubbles in 2008, and to the ongoing Euro zone turmoil - have had systemic implication on the survival and growth of firms in different corners of the world, even before reactions were taken to try to disentangle the links. Shocks in access to financing and to commodities were magnified at an unprecedented scale.

To a considerable extent, participating and competing in GVCs have become inevitable. Even if a firm is not export-oriented, it will be competing against imports made in the global economy unless there are protectionist barriers against imports. This paper looks at the risks and opportunities firms and their workers face in GVCs. First, it examines the risk-sharing mechanisms that firms provide from the national and global perspectives; second, it takes a closer look at the new opportunities and challenges for firms and individuals in the global arena; third, it discusses the role of economic upgrading and social upgrading; and finally it sheds light on how the government can help people manage risks and reap the benefits of participation in GVCs.

This paper draws from an extensive literature on GVCs, much of which has been based on country- and industry-specific field studies by interdisciplinary researchers. The GVC studies reviewed here span a wide range of extractive, agricultural, manufacturing and service sectors, with an emphasis on trends during the past 10-15 years. Our objective is to reframe the findings from this literature on the global economy to useful generalizations about risks and opportunities of participating in GVCs.

\section{FIRMS AS A VEHICLE OF RISK SHARING}

Nobel laureate Ronald Coase has argued that firms emerged as a form of social institution to overcome the constraint of transaction costs inherent in direct exchanges: the costs associated with searching for, communicating, and bargaining with possible trading partners (Coase, 1937). Through efficient resource allocation, firms are capable of generating higher income than households alone can do by providing self-produced goods and services directly to the market. Sharing with another party the burden of loss or the benefit of gain from a risk is a common measure of risk management. Importantly, multi-person firms provide the mechanism of risk sharing among workers, firm owners, and between workers and firm owners:

- When risk is shared among workers, if a worker falls sick, others can share the workload to keep the firm going. Also, the risk-sharing mechanism that multi-person firms make possible allows workers to specialize and increase productivity together. Investing in specialized skills is a risky undertaking. By absorbing the costs of initial training, or by providing incentives to acquire such skills by raising wages, enterprises can tilt workers' skills profiles toward specialization. By sharing the costs of training or increasing the expected returns of acquiring skills, the enterprise sector can shift the skill distribution in the workforce toward specialization (Acemoglu \& Pischke, 1999; Lam \& Liu, 1986).

- When risk is shared among owners of capital, for example, with limited liability, investors can take on more creative risk with a given level of expected risk through diversifying their portfolio. As the Economist magazine noted in its millennium issue, "The modern world 
is built on two centuries of industrialization. Much of that was built by equity finance which is built on limited liability."1 With the required legal and institutional frameworks, the contractual arrangements of limited liability limit the down-side risk of investments, allowing investors to separate personal liability from the debt of the production unit. It also enables them to own small pieces of many firms and diversify their investment portfolio, which reduces risk if some of their investments drop in value. Limited liability also led to the development of the stock market, facilitated corporate capital accumulation, and enabled the exploitation of economies of scale.

- When risk is shared between workers and owners of capital, for example through labor contracts, firms can provide insurance to workers who accept a lower wage in exchange for stable income. Firms can provide a steadier stream of wage income to labor owners by isolating some risks related to production. Through labor contracts, workers can relocate risks in the production process to firms and limit excessive fluctuations in employment and income to maximize welfare. To maximize profit, firms try to minimize the cost of labor as well as the cost of other inputs. To maximize welfare, workers prefer jobs not only with higher but also more stable income. Firms, which are less risk-averse than workers, care more about the average labor cost than its volatility, and thus can offer labor contracts with less volatility in pay (for example, a fixed wage) to compete for workers in exchange for a lower average level of remuneration. By leveraging the two aspects explicitly or implicitly contained in labor contracts - the level and the volatility of the remuneration both firms and workers could be better off through risk sharing. On the other hand, workers can offer a form of insurance to firms in which they agree to reductions in wages or cutback in work hours during temporary shocks in exchange for higher wages in normal times.

Risk sharing and diversification have encouraged risk taking, and increased productivity at a massive scale. Higher income allows individuals to increase savings, purchase market insurance, improve access to finance, invest in nutrition and health, and obtain more knowledge from educational investment. Take savings, for example. If individuals are struggling to meet their current needs, saving for the future will be a slow process. Around the world, as income levels rise, savings rates also rise (Schmidt-Hebbel et al., 1992). In developing countries, a doubling of income per capita is estimated to raise the long-run private savings rate by 10 percentage points of disposable income (Loayza et al., 2000).

However, with the division of labor and diversification of ownership of firms, new risks also emerge. The ways the enterprise sector functions and manages risk affect the risks people face and the risk management measures they employ. Firms may take risk irresponsibly at the brink of bankruptcy, creating negative externalities for society. The management of the firm, which is often in the hands of professionals who have special managerial skills, may have different interests than its owners.

If the enterprise sector fails to function smoothly or if it shifts its own risks to people, it can be a source of risks to households, communities, and even the financial sector and national government. When business shrinks or technology becomes obsolete, the enterprise sector may generate income-related risks (channeled through loss of jobs and loss of capital returns) and asset-related risks (channeled through loss of investments). Both can further translate into risks related to social inclusion, ranging from loss of insurance and other benefits provided through employment (such as health insurance and pension), to loss of connection with the professional community, loss of social status and involuntary changes in life styles. Regulation and incentive systems need to be in place to ensure that the interests of various stakeholders are protected.

In a globalized world, characterized by lower transport and transaction costs, the interconnectedness across firms or sectors linked through supply networks or financial linkages

The Economist, 31 December 1999, Millennium issue. 
multiply and intensify. Global value chains include two main types of firms: "lead firms," which are typically transnational corporations (TNCs) headquartered in the advanced industrial countries, who control and define the main activities in terms of price, delivery and performance in both producer-driven and buyer-driven GVCs; and the supplier companies who produce the goods and services in GVCs, generally located in developing countries. Thus, the GVC "enterprise sector" links both developed and developing countries into a common global supply chain (Gereffi and Sturgeon, 2013).

From the GVC point of view, enterprise sectors in national economies are part of the supply base for lead firms in GVCs. This has two concrete implications: (1) external actors (specifically, GVC lead firms) are a potentially significant form of "external risk" in national enterprise sectors; and (2) national enterprise sectors are nested within larger regional and global enterprise sectors, which are connected to GVCs. The global enterprise sector, as a series or set of industry-specific GVCs, has the potential to affect people's risk management through the same risk-sharing mechanisms that are operating at a larger scale. It can be advantageous or detrimental to national enterprise sectors and affect firms differently according to their size and industries.

\section{OPPORTUNITIES AND CHALLENGES IN THE GLOBAL ARENA}

Firms face new opportunities and challenges in the global market. They have the opportunities of supplying much larger global demand, which eliminates the scale and purchasing power limitations of the domestic market in developing economies. There also are many more upgrading opportunities because the quality and price parameters have wider variation, allowing for more extensive product and process upgrading options. There is also higher risk because international standards for price, quality, and delivery schedules are much less forgiving. Firms typically need a relatively large scale of production to participate in global markets, or have a special technological edge to enter global market niches. There is also a risk from intensified competitive pressures, as everyone can compete with exporters in terms of lower prices or higher quality, so only the best can succeed in GVCs.

The presence of scale economies favors the concentration of production, which tends to minimize costs, leading to higher profits for enterprises and possibly lower prices for consumers. The higher concentration of production yields benefits of large-scale clustering and agglomeration, but also generates new risks for the economy. Shocks in one location can easily spread to the rest of the network, generating cascade effects. If the supply network is highly interconnected, low productivity in one sector can potentially affect the entire economy, as downstream sectors will also suffer (Acemoglu et al., 2010).

The effects of the 2011 earthquake in Japan on the automobile industry worldwide demonstrate the vulnerability of the system to shock (Box 1). However, greater openness to international trade and capital can also have a large impact on macroeconomic volatility. When an economy is highly concentrated in certain productive activities, such as Nokia (whose worldwide sales in 2003 represented over one-quarter of Finland's GDP) and Samsung (which accounted for 23 percent of the Republic of Korea's exports and some 14 percent of GDP), firm-specific idiosyncratic shocks can generate significant shocks that affect GDP (Di Giovanni \& Levchenko, 2009). In the United States, the largest and most diversified economy in the world, a one-time increase of the dividend of one company (Microsoft, for $\$ 32$ billion) boosted growth in personal income from 0.6 percent to 3.7 percent in December 2004 (Bureau of Economic Analysis, 2005). I added this reference to the bibliography.

While firms are exposed to new challenges in an increasingly integrated world, international trade and financial linkages, remittances, and diaspora communities also have the potential to 
serve as safety nets for individuals, families, and communities to absorb and cope with risks to shocks that are not global in nature.

Foreign direct investment can affect the volatility of enterprise performance in times of crisis in different ways. The ability of multinationals to shift production across countries can increase volatility, and market diversification can lend stronger stability to local subsidiaries. For instance, after the recent global financial crisis, multinational subsidiaries linked to parents with strong vertical production and financial linkages fared better on average than local counterparts. The demand from parent firms can help absorb the negative demand shock in the host country, while the performance of subsidiaries linked horizontally with parent firms might become more volatile as the multinationals shifts more production back home (Alfaro \& Chen, 2011).

\section{Box 1.}

From one shock to another: The 2011 earthquake in Japan rattled the auto industry worldwide

Supply chain management, backed by tight vertical connections among enterprises, has resulted in a high level of competitiveness for the automobile industry. Car makers at the top of a chain can procure meticulously customized, high-quality components from firms further down the chain (resulting in differentiated, high-quality cars), collect information to continuously predict the appropriate amount of outputs, and minimize inventory and associated costs.

The high degree of customization and just-in-time production practice, two key drivers of success, also expose the automobile industry to worldwide shocks (Canis, 2011). In March 2011, an earthquake struck eastern Japan. The disruption of production of automotive parts generated immediate impacts. Since automotive parts are highly customized, replacement from other suppliers is almost impossible. In April 2011, Nissan closed plants in Mexico for five days and plants in the United States for six days. Output at eight of Honda's Canadian, Indian, U.K., and U.S. plants was cut by half. The U.S. car maker, General Motors, closed its assembly plant in Louisiana because of a shortage of vehicle parts, which in turn led to short layoffs at its New York, plant, where the engines are made. Ford closed assembly plants in Belgium and the United States for one week, and plants in China, the Philippines, Taiwan, China, and South Africa for two weeks.

"Piecing Together a Supply Chain,” New York Times, May 12, 2011.

The internal capital markets and investment flows in TNCs from parents to subsidiaries can lower subsidiaries' dependence on host-country credit conditions and hence lower their performance volatility when host countries experience credit crunches (Antras et al., 2009). In Poland, for example, during the recent global economic crisis, foreign ownership appears to have provided a higher degree of resilience to affiliates facing external credit constraints through intragroup lending mechanisms (Kolasa et al., 2010).

For individuals, communities, and national economies, remittances of foreign earnings tend to be stable and often countercyclical. Migrants are likely to send home more resources to help their families when the home country has experienced an economic downturn or crisis. For example, during the financial crisis in Mexico in 1995 and in Indonesia and Thailand in 1998, remittances increased sharply, which not only helped household smooth consumption, but also provided the needed resources to overcome credit constraints for local entrepreneurs, alleviating their risks (The World Bank, 2005). Beyond remittances, diasporas can provide assistance in normal times by assisting in philanthropic activities, fostering the exchange of knowledge, and increasing trade links; in time of stress, they are more likely than average investors to finance infrastructure, housing, health, and education projects in their countries of origin. Diaspora bonds have raised over $\$ 35$ billion in India and Israel, including periods when the home country was suffering a liquidity crisis (Ratha, 2010).

In terms of GVCs, the "rationalization" that has been going on in terms of shrinking the size of supply chains was accelerated as a result of the 2008-2009 global economic recession. As consumption declined in most advanced industrial countries, which were the main markets 
for GVCs, the size of GVC supply chains sharply contracted as a result of the recession. Recent studies have highlighted significant new trends in how GVCs are organized in the current period, which alter the nature of risks that national enterprise sectors will confront (see Gereffi (2014), for a summary of these changes):

- GVCs are becoming geographically more consolidated, which reflects the rise of large emerging economies after 1989. Known initially as BRICs (Brazil, Russia, India and China), the emerging economies now include a diverse array of "growth economies" such as Mexico, South Korea, Turkey, Indonesia, the Philippines, and Vietnam, which offer seemingly inexhaustible pools of relatively low-wage workers, highly capable exportoriented manufacturers, abundant raw materials, and sizeable domestic markets (O'Neill, 2011). Emerging economies are now major production centers worldwide, although their specific roles in GVCs vary according to their openness to trade and foreign investment, and other strategic considerations.

- GVCs are also organizationally more concentrated, as the transnational lead firms in GVCs seek to shrink their global supply chains from 500-1,000 suppliers in the heyday of economic globalization in the 1990s and early 2000s to 25-30 key suppliers (or less) in the current era. These new supplier firms are expected to be bigger, more capable (technologically as well as in modern models of supply-chain management), and strategically located to access large regional and national markets. Coupled together, the trends of GVCs toward geographic consolidation and organizational concentration place greater competitive pressures and economic risks on the majority of countries and firms in the global economy that don't have the scale, size, strategic location, or skills to rise to the top in contemporary GVCs.

The global economic recession of 2008-2009 has reinforced some of the pre-existing trends in GVCs, but also introduced new patterns in the global economy that affect the distribution of risk and vulnerability in national enterprise sectors. A study by the World Bank concludes that GVCs have proven resilient in the face of the recent economic crisis, which has accelerated two longterm structural trends in the global economy: the aforementioned consolidation of GVCs, and the growing salience of markets in the developing world (Cattaneo et al., 2010: 6). As world trade is bouncing back from the 2008-2009 global recession, emerging economies are becoming a main engine of world economic recovery. Given stagnant consumer demand in the developed world, GVCs are shifting to supply new end markets in the developing world, which include a renewed emphasis on the domestic markets of large emerging economies and the regionalization of what were previously global supply chains (Staritz et al., 2011).

In the case of the global apparel industry, between 1995 and 2009, China's share of global apparel exports increased from $22 \%$ to $41 \%$, and export sales increased from US\$32.9 billion to $\$ 122.4$ billion. Countries whose market shares declined most abruptly during this period, which included the phase out of the Multi-Fiber Arrangement (MFA) in 2005 that guaranteed export quotas for many smaller countries in U.S. and European Union markets, were Mexico, Central America and the Dominican Republic, Thailand, the Philippines, Romania and Poland (Frederick \& Gereffi, 2011). However, even in China, a clear winner in aggregate terms, thousands of apparel factories were shuttered and millions of workers in apparel plants lost their jobs as the industry was streamlined in the late 1990s and early 2000s (when many state-owned apparel firms were closed), and then again in the late 2000 s as the recession further reduced export-oriented sales.

In short, the economic crisis has not reversed globalization; international production and consumption have remained central features of the global economy. The role of the developing world compared with that of the developed countries has grown, but inequalities among developing countries in terms of how they are positioned in GVCs are rising as well. In producerdriven chains, the lead firms that to a large degree defined the structure of these industries were mainly global manufacturers like General Motors, Ford, IBM, and HP. In buyer-driven chains, 
the lead firms were a mix of retailers (like Walmart, JCPenney, and Carrefour), global marketers (such as Nike, Liz Claiborne, and Polo Ralph Lauren), and supermarkets and food multinationals (like Tesco, Sainsbury's, Kraft Foods and Nestlé) (Gereffi, 1994). The lead firms in buyer-driven chains were particularly influential in the globalization process because they accelerated the process of "global sourcing" based on orders from developed countries, which relied almost entirely on production carried out in developing economies (Gereffi, 1999; Dicken, 2011). The dominant role the lead firms (largely from the developed world) could generate additional sources of inequality and potential crises in the future.

\section{ECONOMIC UPGRADING AND SOCIAL UPGRADING}

The distribution of risks and opportunities is closely related to the positioning of an enterprise within a value chain and to the nature of this value chain. Figure 1 illustrates this proposition for value chains associated, respectively, with five different industry groups. Economic and social upgrading (or downgrading) of firms and workers can take place in multiple trajectories (Barrientos et al., 2011).

The concept of social upgrading refers to improvements within a specific enterprise (or associated group of enterprises) in the terms of employment, remuneration, worker rights, and workplace safety and employee insurance arrangements (Barrientos et al., 2011). Social upgrading is central to this examination of household risks and enterprises within value chains. Social upgrading by enterprises helps reduce risks for worker households and removes some of the volatility that they would otherwise face. The extent and type of social upgrading that is possible are usually related to (but not solely determined by) the economic upgrading in place, which highlights improvements in various aspects of economic performance within GVCs. Other institutional factors and actors, including the extent and nature of worker organization, civil society actions, government legislation and its enforcement, can also make a difference.

Figure 1.

Industry Groups, GVCs, and Economic Upgrading

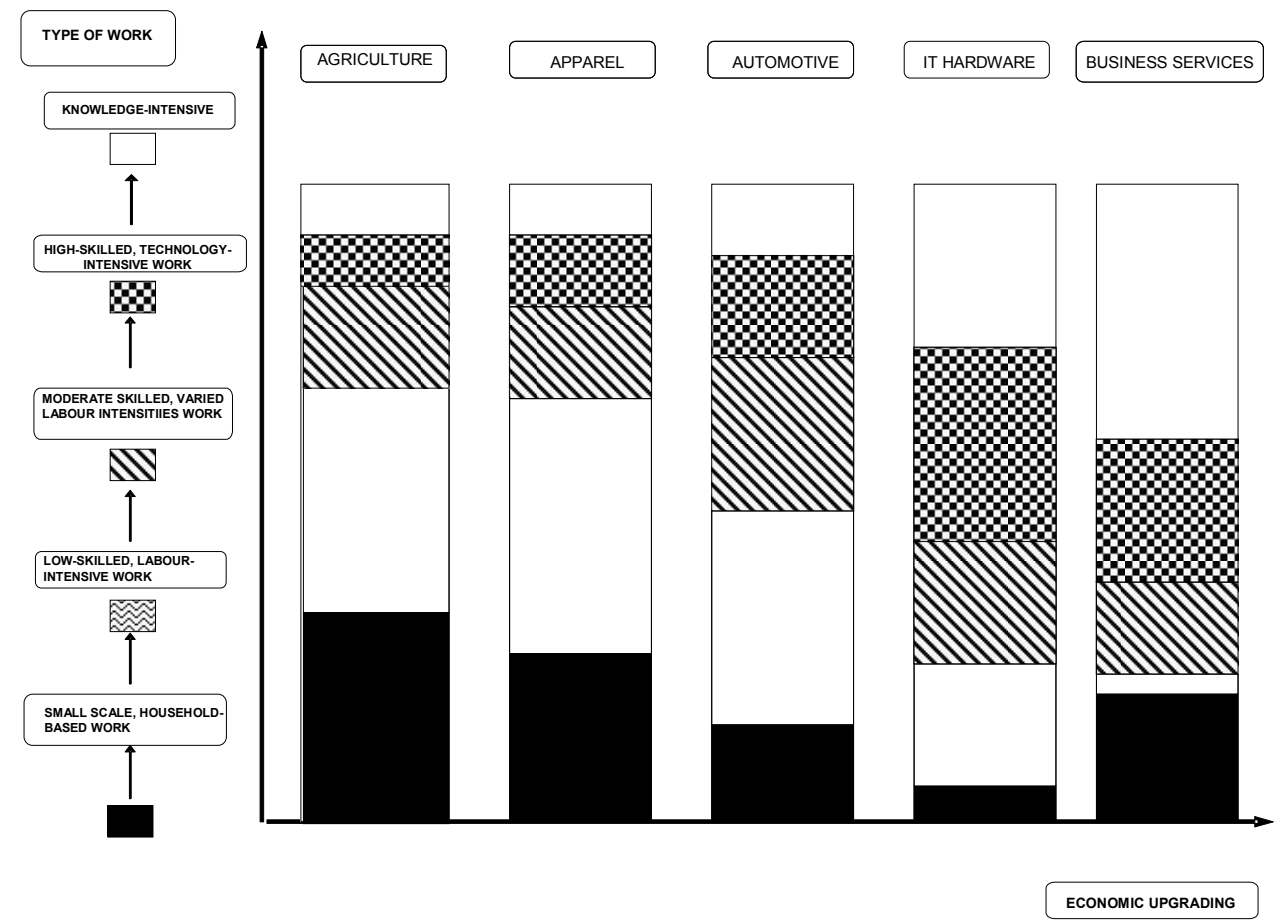

Adapted from Barrientos et al. (2011). 
Each GVC in Figure 1 is represented as a vertical silo, with lower segments signifying the approximate share of less-skilled types of work carried out within the value chain. All value chains include economic activities that span a broad range of skill levels. Consider agriculture, for example. At the lowest level - the farm, typically - this value chain involves a relatively large proportion of small scale and low-skill labor. Higher in the value chain, particularly at the points of processing and marketing, the skill level of workers rises progressively. The same is true for each of the other four GVCs. Skill levels rise as one moves from lower to higher value activities in the chain; the proportion of highly skilled workers at the top of each value chain, who carry out knowledge-intensive activities, vary according to the type of $\mathrm{GVC}$ we are examining. In agriculture, for example, this segment tends to be relatively small, while in business services, the proportion of knowledge workers is relatively large

The likelihood of enforceable standards also rises as one moves up value chains toward more formal and skill-intensive work. It is not enough merely to specify decent work standards; they must be capable of enforcement at low cost, in the ideal situation being self-enforcing. The prospects of having measurable and enforceable standards typically rise as skill levels and technology increase within value chains.

Social upgrading can be achieved through various means, involving different combinations of: (a) economic upgrading: as enterprises move up value chains, the share of skilled workers typically increases; and (b) deliberate actions to introduce enforceable standards - minimum wages, paid time off, workplace safety, insurance, and so on - for those workers whose skill levels remain low, who are more easily replaced, and who for these reasons may be badly treated. The scope for such actions widens considerably as the array of actors is expanded in GVCs. Using illustrative examples of successful social upgrading, we develop an analytical framework to assess possibilities for action.

Alternative pathways for social upgrading are available, as Figure 2 shows with the help of three examples. The first example, Pathway A, depicts a situation in which no significant economic upgrading has occurred. Instead, risks to workers were reduced because of deliberate actions that introduced enforceable standards. This could be the situation, for instance, of an enterprise that produced t-shirts branded with the logo of some U.S. university. Actions by concerned student groups resulted in a slew of reforms: doing away with child labor, reducing the length of the work day, improved lighting and other work conditions, and so on.

Figure 2.

Different Pathways to Social Upgrading

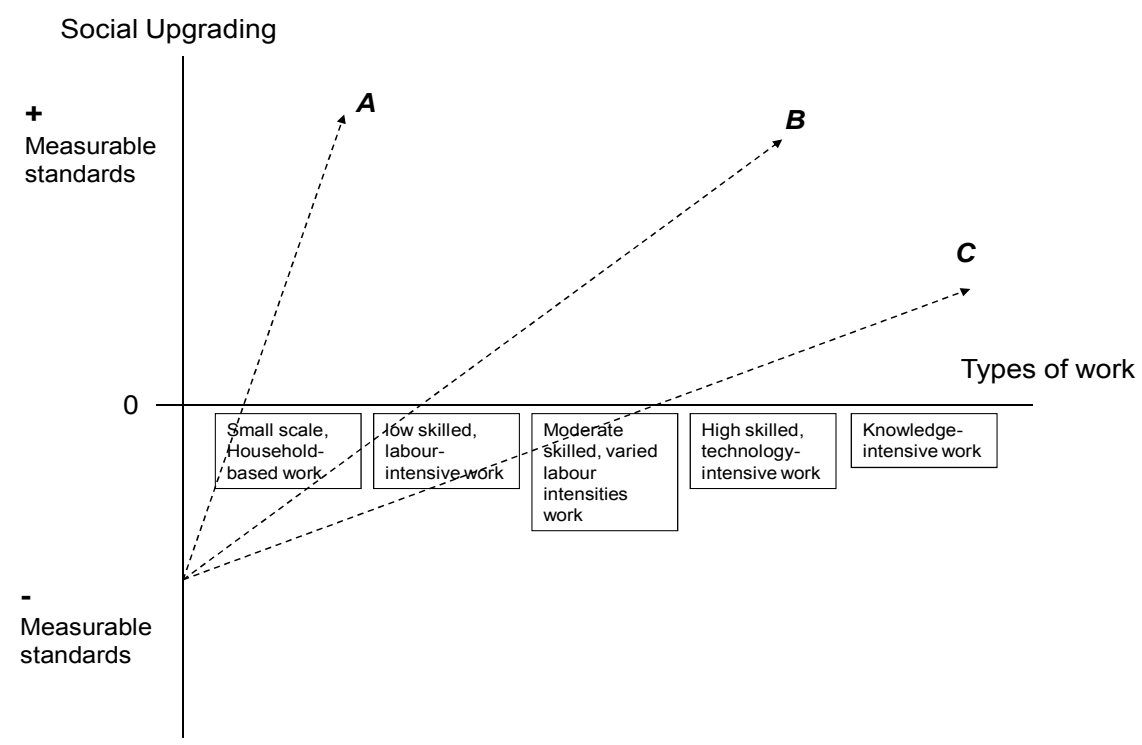


Alternatively, social upgrading can occur along Pathway $\mathrm{C}$, where almost the entire burden is borne by economic upgrading. In this case, risks for workers are reduced as small-scale household work gets turned over into high-tech and knowledge-intensive work, for instance, as in the case when a weaver of traditional rugs takes to computerized design and manufacturing. In the intermediate case of Pathway B, social upgrading within labor-intensive industries like apparel can be achieved with lower risks to workers if outside institutions like the Better Work program run by the International Labor Organization are involved to help certify standards (Rossi et al., 2014).

When the enterprise sector gravitates toward more technology- or knowledge-intensive industries - for example from agriculture to apparel, and to business services - the share of skilled workers typically increases. As a result, labor productivity grows and more jobs of higher quality are created. However, economic upgrading does not always lead to social upgrading in the form of better wage and working conditions. On the one hand, unskilled workers in many developing countries can be excluded from the desirable job opportunities provided by technology-intensive or knowledge-intensive work, which tends to concentrate in more developed countries. On the other hand, workers in the same enterprises can face very different opportunities for social upgrading; regular workers can have better statutory employment protection and benefit from labor standards, while irregular workers, often over-represented among women, youth, minority, and other vulnerable groups, can suffer discrimination.

In many enterprises in the developing world, hiring irregular workers directly or through thirdparty contractors to perform the most time-sensitive task in the low (unskilled) segment of the production chain, is often a way for firms to reduce costs in response to last-minute orders from outsourcing companies. While this creates new employment opportunities for many low skilled workers, it also allows firms to shift the risks of production related to fluctuations in demand to workers. Regulations need to be in place to protect workers.

To a considerable extent, as we contend below, reducing risk for workers / households is associated with social and economic upgrading at the enterprise (or industry) level. Since a significant proportion of international production and trade now takes place through coordinated value chains in which lead firms globally and locally play a dominant role, possibilities for upgrading are increasingly defined by firms' locations within these chains.

Firms in GVCs have opportunities for economic upgrading through engaging in higher value production within value chains. However, they also face challenges meeting the commercial demands and quality standards required by buyers, which smaller and less efficient producers find hard to meet (Gereffi \& Lee, 2012; Gereffi, 2014). The GVC approach focuses heavily on this notion of inter-firm networks, which exist within corporate supply chains, and international trade and production networks. Adopting a GVC approach to a considerable extent changes the focus of our analysis: instead of looking at individual, self-contained enterprises, we need to examine how firms are positioned within chains having different structures.

Adopting a GVC analytical framework opens the door, therefore, to an additional cast of economic actors and stakeholders who can act as agents of change. In addition to governments and enterprise management, national industry associations, and trade unions, positive change in working conditions can be brought about at the initiatives also of buyers' associations, consumer groups, and international certification and inspection agencies, increasingly employed by buyers wary of their international human rights image (Mayer and Gereffi, 2010).

The expansion of global production, especially in labor-intensive industries, has been an important source of employment generation. Many jobs have been filled by women and migrant workers who previously had difficulty accessing this type of waged work, and they have provided new income sources for poorer households (Oxfam International, 2004; Barrientos et al., 2003). Where this is regular employment that generates better rights and protection for workers, it can enhance social upgrading and decent work. The demand for rising standards often requires the skilling of at least some workers and provision of better employment conditions. 
But for many workers, this is not the outcome. Much employment is insecure and unprotected, and there are significant challenges ensuring decent work for more vulnerable workers. Irregular and low-skilled jobs - which are also low paying, thereby representing limited prospects for upward mobility - are as easily eliminated as brought into being. New risks are introduced, even as some old ones abate. Along with the risk of dismissal (or work reduction) that especially lower-skilled workers (and suppliers) of enterprises face, another significant downside risk accompanying these engagements involves the enhanced probability of injury and illness. Unsafe and unsanitary work conditions are often associated with low-skilled work in the enterprise sector. Labor safety regulations are non-existent or they are routinely flouted, more so at some and less at other points within GVCs (Rossi et al., 2014).

Poorer individuals' engagements with the enterprise sector thus produce situations that can be, and often are, volatile. A simple logic for why volatility can be greatest for the worst off in these relationships is provided by Barrientos et al. (2011: 332): "challenges...remain significant for irregular workers... New activities taken on by the factory may well...lead to social upgrading for regular workers - through the development of more skills and training for new capabilities - but irregular workers continue to be needed in order to respond to buyers' requirements in terms of low cost, short lead times and high flexibility; their very status impedes their social upgrading."

Not all developing countries face similar options in the context of these changes. The shift to Southern markets and the growth in South-South trade have created more possibilities for entry and upgrading in GVCs, but they also present new challenges, particularly for the least-developed countries. GVC consolidation poses opportunities as well, especially for countries and firms with rising capabilities. However, it too threatens to leave many countries and firms that don't possess the required advantages on the periphery of GVCs.

In a more promising vein, the GVC literature shows that value chains oriented to different end markets entail distinct upgrading opportunities (Staritz et al., 2011; Gereffi, 2014). For example, the demand in lower-income countries for less sophisticated products with regard to quality and styles may confront lower entry barriers and less stringent product and process standards, which can facilitate participation and make it easier for developing country firms to engage in higher value-added GVC activities (such as product development, design, and branding) (Kaplinsky et al., 2011). With more intimate knowledge of local and regional markets than multinational firms, they can generate "frugal" innovations that are suitable to resource-poor environments (Clark et al., 2009). On the other hand, relying exclusively on low-income markets can lock suppliers into slimmer margins and cutthroat competition, which heightens economic risks.

Rossi's (2011) case study of garment factories in Morocco led by fast-fashion buyers shows that functional upgrading in GVCs can bring about social upgrading and downgrading simultaneously, for regular and irregular workers, respectively. On the one hand, factories supplying a finished product and overseeing packaging, storage and logistics for their buyers offer stable contracts and better social protection to their high-skilled workers to ensure a continuous relationship as well as full compliance with buyers' codes of conduct. On the other hand, in order to be able to respond quickly to buyers' frequently changing orders and to operate on short lead times, they simultaneously employ irregular workers on casual contracts, especially in the final segments of the production chain (such as packaging and loading), often imposing excessive overtime as well as discriminating against them on the basis of wages and treatment (Rossi, 2011).

In agri-food GVCs, private quality standards set by highly concentrated European and U.S. supermarkets and food manufacturers have a direct impact on risks faced by consumers as well as farmers, with conflicting implications for safety and upgrading (Lee et al., 2012). On the one hand, stringent food safety and quality standards imposed by large food retailers and manufacturers, which generally have extensive global sourcing networks, protect consumers against social and environmental risks. However, these tend to marginalize small farmers unable to comply because of high costs and a lack of required skills and facilities (e.g., cold chains to store, distribute and 
ship fresh produce). On the other hand, higher standards can be a catalyst for participation in high-value-added chains, such as the role played by smallholders who successfully supply niche markets for organic or Fair Trade-certified products (Gereffi \& Lee, 2012: 28).

In both developed and developing countries, the economic gains of participating in global supply chains do not necessarily translate into good jobs or stable employment and, in the worst case, economic upgrading typified by a number of successful export economies, especially in low-income countries, may be linked to a significant deterioration of labor conditions and other forms of social downgrading (Rossi et al., 2014).

A recently concluded three-year research program funded by the United Kingdom's Department for International Development, called Capturing the Gains (UK DFID, 2013), has a website containing many of the research findings in working papers and policy briefs. One of the main conclusions of this project is that GVCs can be a key policy tool for sustained poverty reduction. However, facilitating the upgrading of workers and smallholders also requires publicprivate-civil society partnerships, as well as regional partnerships involving countries and firms that lead international production networks based in Asia, Africa and Latin America, which are key to future upgrading of the South (Lee et al., 2011). These partnerships reflect novel forms of risk sharing and strategic collaboration among key value chain actors to address the challenge of promoting widespread and sustainable development.

Various examples of novel partnerships for risk sharing, innovation and upgrading are identified in the Summit Briefings for the Cape Town, South Africa meeting held in December, 2012. A few of these are found in Barrientos et al. (2012: 3-4). For example, over recent decades, the cocoa-chocolate value chain has undergone concentration in processing and manufacturing. Cocoa farmers have received limited support, often have low yields and are poorly remunerated. Media attention has highlighted issues of child labor, and many younger innovative farmers are leaving the sector for better options elsewhere. Consumption of chocolate has grown steadily, especially in emerging economies, with predictions of future cocoa shortages. Leading chocolate manufacturers are working with civil society, donors and governments to support farmers and their communities. Social upgrading is now recognized as critical to economic upgrading - and ensuring the future resilience of the cocoa-chocolate value chain.

\section{POLICY IMPLICATIONS}

Overall, the government can provide a critical supportive environment in terms of infrastructure to help exporters, local communities and small producers trying to access national and international markets, education and training to build a skilled labor force, and sensible regulations to lower the uncertainties.

Firms benefit most from participation in GVCs if they are relatively large, technologically advanced, professionally managed, and have diversified export markets (both in terms of products and countries). Suppliers also benefit from relatively close relationships with their buyers, which can facilitate learning how to upgrade to meet the standards of global markets. These findings accommodate current GVC trends, since TNCs seek to reduce transaction costs by requiring "onestop shops" with larger and more capable suppliers. Contract manufacturers and business process outsourcing service providers, and firms that provide routine assembly tasks and other simple services within GVCs earn slimmer profit, and provide less to their workers (Lüthje, 2002).

Workers benefit most from participation in GVCs if their conditions of work are relatively formalized (e.g., wages, length of work day and work week, defined benefits) and if they have higher skills (closely correlated with more advanced education) that allows them to carry out better remunerated tasks. The government can play a key role to address the downside risks for workers - dismissal, debt, injury, illness - and assist in enhancing the upward mobility 
simultaneously. Enforcing sound regulations dealing with labor conditions is crucial to protect the vulnerable segment of the labor force.

Global buyers (retailers, brands, supermarkets) typically don't pay suppliers to undertake the upgrading required to remain competitive in GVCs. Therefore, supportive government policies are an asset (e.g., helping firms to meet international standards and certification requirements, or providing loans or access to finance capital required for purchasing new or better equipment).

The policy implications for upgrading in terms of different end markets are not clear cut. Facilitating access for export producers to multiple end markets through preferential trade agreements (multilateral or bilateral) would increase the flexibility for suppliers in developing countries to engage in upgrading. However, this will also expose them to greater competitive pressures through low-cost imports. More fundamentally, government policy makers don't know enough about the intricacies of global industries to spur specific forms of innovation in GVCs.

There is no magic bullet to improve international competitiveness in GVCs. What government policy can do is to facilitate the development of human capital, including collaborations with universities and private firms to ensure demand-responsive forms of workforce development. In addition, government can foster global collaboration by making it easier for small and mediumsized firms to gain the information they need about global markets, and also to sponsor local trade fairs or external trade missions to encourage global match-making.

\section{Acknowledgement}

This paper was prepared as a background paper of the World Development Report 2014: Risk and Opportunity. The findings, interpretations, and conclusions expressed in this paper are entirely those of the authors. They do not necessarily represent the views of their affiliated organizations.

The authors would like to thank Anirudh Krishna for valuable discussions and comments.

\section{References}

Acemoglu, D., \& J.-S. Pischke (1999), “The Structure of Wages and Investment in General Training”, Journal of Political Economy, 107(3), 539-572.

Acemoglu, D., A. Ozdaglar, \& A. Tahbaz-Salehi (2010), “Cascades in Networks and Aggregate Volatility”, Mimeo.

Alfaro, L. \& M. Chen (2011), "Surviving the Global Financial Crisis: Foreign Ownership and Establishment Performance", http://home.gwu.edu/ xchen/crisis_MNC.pdf.

Antras, P., M. Desai, \& F. Foley (2009), "Multinational Firms, FDI Flows and Imperfect Capital Markets", Quarterly Journal of Economics, 124(3), 1171-1219.

Barrientos, S., C. Dolan, \& A. Tallontire (2003), "A gendered value chain approach to codes of conduct in African horticulture", World Development, 31(9), 1511-1526.

Barrientos, S., G. Gereffi, \& D. Nathan (2012), "Economic and social upgrading in global value chains: Emerging trends and pressures", Capturing the Gains Summit Briefing, December http://www.capturingthegains.org/ pdf/CTG-GVC.pdf, (accessed 9 May 2015).

Barrientos, S., G. Gereffi, \& A. Rossi (2011), "Economic and social upgrading in global production networks: A new paradigm for a changing world.” International Labour Review, 150(3-4), 319-340.

Bureau of Economic Analysis (2005), "Like the Personal Income Numbers. Thank Microsoft.” January 31, http:// macroblog.typepad.com/macroblog/2005/01/like_the_person.html.

Canis, B. (2011), “The Motor Vehicle Supply Chain: Effects of the Japanese Earthquake and tsunami”, Congressional Research Service (CRS) Report for Congress, R41831.

Cattaneo, O., G. Gereffi, \& C. Staritz (eds) (2010), Global Value Chains in a Postcrisis World: A Development Perspective, TheWorld Bank, Washington, D. C.

Clark, N., J. Chataway, R. Hanlin, D. Kale, R. Kaplinsky, L. Muraguri, T. Papaioannou, P. Robbins, \& W. Wamae (2009), "Below the Radar: What Does Innovation in the Asian Driver Economies Have to Offer Other Low 
Income Economies?”, INNOGEN Working Paper No. 69, Milton Keynes, UK, http://oro.open.ac.uk/15241/ (accessed 20 February 2013).

Coase, R.H. (1937), “The Nature of the Firm”, Economica, New Series 4(6), 386-405.

Di Giovanni, J., A. Levchenko (2009), "International Trade and Aggregate Fluctuations in Granular Economies", Working Paper, University of Michigan, http://crei.cat/files/filesActivity/34/di\%20giovanni.pdf.

Dicken, P. (2011), Global Shift: Mapping the Changing Contours of the World Economy, 6th ed. New York: Guilford.

Frederick, S., \& G. Gereffi (2011) "Upgrading and Restructuring in the Global Apparel Value Chain: Why China and Asia are Outperforming Mexico and Central America”, International Journal of Technological Learning, Innovation and Development, 4(1-3): 67-95.

Gereffi, G. (1994), "The organization of buyer-driven global commodity chains: How US retailers shape overseas production networks.” In G. Gereffi \& M. Korzeniewicz (eds.), Commodity Chains and Global Capitalism (pp. 95-122): Westport, CT: Praeger Publishers.

Gereffi, G. (1999), "International trade and industrial upgrading in the apparel commodity chain." Journal of International Economics, 48(1): 37-70.

Gereffi, G. (2014), “Global value chains in a post-Washington consensus world”, Review of International Political Economy, 21(1): 9-37.

Gereffi, G. \& J. Lee (2012), "Why the world suddenly cares about global supply chains", Journal of Supply Chain Management, 48(3), 24-32.

Gereffi, G., and T. Sturgeon (2013), "Global value chains and industrial policy: The role of emerging economies." In Deborah K. Elms \& Patrick Low (eds.), Global Value Chains in a Changing World (pp. 329-360). Geneva: World Trade Organization, Fung Global Institute and Termasek Foundation Centre for Trade and Negotiations.

Kaplinsky, R., A. Terheggen, \& J. Tijaja (2011), "China as a Final Market: The Gabon Timber and Thai Cassava Value Chains", World Development, 39(7): 1177-1190.

Kolasa, M., M. Rubaszek, \& D. Taglioni (2010), "Firms in the great global recession: The role of foreign ownership and financial dependence", Emerging Markets Review, 11(4), 341-357.

Lam, K.C., \& P.W. Liu (1986), "Efficiency and sharing of investment in specific human capital under risk aversion", Economics Letters, 20(1), 83-87.

Lee, J., G. Gereffi, \& J. Beauvais (2012), “Global Value Chains and Agrifood Standards: Challenges and Possibilities for Smallholders in Developing Countries", Proceedings of the National Academy of Sciences of the United States of America, 109(31): 12326-12331.

Lee, J., G. Gereffi, \& S. Barrientos, (2011), “Global Value Chains, Upgrading and Poverty Reduction”, Capturing the Gains Briefing Note No. 3, November, http://www.capturingthegains.org/pdf/ctg_briefing_note_03.pdf (accessed 9 May 2015).

Loayza, N., K. Schmidt-Hebbel, \& L. Serven (2000), “What drives private saving around the world?”, Policy Research Working Paper Series, No. 2309, The World Bank, Washington, D. C.

Lucas, R.E., Jr. (2002). Lectures on Economic Growth. Cambridge: Harvard University Press. pp. 109-110. ISBN 978-0-674-01601-9.

Lüthje, B. (2002), "Electronics contract manufacturing: Global production and the international division of labor in the age of the Internet." Industry and Innovation, 9(3): 227-247.

Mayer, F. and G. Gereffi (2010), "Regulation and economic globalization: Prospects and limits of private governance", Business and Politics, 12(3), Article 11.

O'Neill, J. (2011), The Growth Map: Economic Opportunity in the BRICs and Beyond, New York: Penguin.

Oxfam International (2004), Trading Away Our Rights: Women Working in Global Supply Chains, Oxford: Oxfam International.

Ratha, D. (2010), "Diaspora bonds for development financing during a crisis”, http://blogs.worldbank.org/ peoplemove/node/1303.

Rossi, A. (2011), "Economic and social upgrading in global production networks: the case of the garment industry in Morocco", DPhil dissertation, Institute of Development Studies at Sussex University, Brighton.

Rossi, A., A. Luinstra, \& J. Pickles (eds.) (2014), Towards Better Work: Understanding Labour in Apparel Global Value Chains. Geneva: International Labour Organization and Palgrave Macmillan.

Schmidt-Hebbel, K., S.B. Webb, \& G. Corsetti (1992), "Household Saving in Developing Countries: First CrossCountry Evidence", The World Bank Economic Review, The World Bank Group, 6(3), 529-547.

Staritz, C., G. Gereffi, \& O. Cattaneo (eds.) (2011), Special Issue on "Shifting End Markets and Upgrading Prospects in Global Value Chains", International Journal of Technological Learning, Innovation and Development $4(1 / 2 / 3)$.

The World Bank (2005), Global Economic Prospects 2006: Economic Implications of Remittances and Migration. Washington, D. C.

United Kingdom, Department for International Development (2013), Capturing the Gains. www.capturingthegains.org. 